UDC 330.1:332.146.2

I. L. Bodnaruk, Cand. Sc. (Econ.),
orcid.org/0000-0003-1608-9786,
L. S. Shlapak, Dr. Sc. (Tech.), Prof.,
orcid.org/0000-0002-4522-7300

\title{
PECULIARITIES OF THE STAGES OF RATING ASSESSMENT FORMATION IN RATING MANAGEMENT SYSTEM
}

Purpose. The study of content features that are inherent in the rating process and methods for forming the rating, which allow ensuring the effectiveness of procedures for decision-making.

Methodology. Theoretical and practical research results were obtained using the following methods: synthesis, analysis - to identify the features of the rating formation and to analyse the evaluation methods; constructive and logical methods - to construct a model of decision-making in the rating management system; logic synthesis, economic and mathematical modeling - to develop a scientific and methodological approach to rating evaluation.

Findings. It was established that the basis of rating process and rating management is the concept of decisionmaking by potential users through the use of ratings in the implementation of the basic management functions. On the basis of the analysis, the general classification of methods for forming the rating was carried out, which enables the secure assessment procedure, effectiveness of management decisions and builds the interconnection circuit of the stages of forming the techniques rating.

Originality. Classification of methods and stages of ratings formation was designed, which makes it possible to take into account the features of rating calculation in decision-making. It was proved that the determining factor is the problem of development of the theory of rating management as well as the process of development and application of scientifically based models of the rating assessment.

Practical value. A scheme of interconnection of formation stages of rating methodologies was built that is provided as a flexible, integrated system that encompasses techniques, methods and models in the management based on rating and allows adopting effective management decisions.

Keywords: rating grade, rating management, the process of rating, classification, evaluation

Intorduction. The fundamentals of rating itself and rating management, which is understood as the concept of making managerial decisions based on the use of ratings in the system of approval and implementation of management functions, are becoming more actual nowadays.

At this stage of development of the Ukrainian economy with the detection of unfavorable trends in the development of systems, the existing methods for the calculation and definition of rating assessments are not sufficiently studied. Therefore, the relevance of the topic is determined by the need for a thorough study and research on the theoretical foundations for rating and rating management.

Analysis of the recent research and publications. Issues of rating management, methodology, estimation and practice of ratings ranking in economics and management are considered in the papers of such domestic economists as: V.A. Batkovskyi, A. P. Belyi, O. I. Bogatov， V.V.Vitlinskyi， Yu. G. Lysenko, A.A. Madykh, V. L. Petrenko, V.G. Skobelev, V. Tymokhin, P. Gorskyi, A. M. Karminskyi, A. Perezetskyi, A. E. Petrov. The topics of the rating management are also covered in studies of foreign scientists such as: Van D. Deventer, L. V. Dukanich, A. M. Messer, Ch. S. Tapiero, A. S. Timchenko, O. Schnek. In particular, the papers of N. Vnukova, A. Yerina, S. Vaschayeva and others are devoted to the use of rating systems as a modern tool for studying and analyzing in various economic systems.

(C) Bodnaruk I. L., Shlapak L. S., 2018
The idea of rating assessment of economic systems and their subsystems is not new. However, the main problem at the present time is the identification and consideration of the actual conditions and parameters for rating (the basis of the rating system of evaluation), which will lead to effective management.

Formulation of the problem. The concept of accepting and adopting certain managerial decisions regarding the customer of services was based on the fundamentals of ranking, where certain management functions were implemented through certain ratings.

The rating process includes a set of methods and approaches for assessing quantitative and qualitative factors, which allows investigating certain types of rating objects, according to which a rating is made, on the basis of which a decision on the management process is made [1]. Like any management system, rating management is implemented in the following basic conditions:

- clear representation of the model of the object of management;

- assessment of the possibilities of the subject of management;

- definition of management objectives;

- formation of methods and criteria for obtaining certain information about the object of management in connection with the realization of goals;

- construction of a certain mechanism of an action regarding objects of management for the implementation of these management objectives.

In Ukrainian economic environment, the use of rating assessments, which ensures the steady development 
of economic processes, has not received the necessary understanding yet. However, it should be noted that the financial market of services is the most attractive for the application of the rating system of our country, especially its insurance and banking sector, which is a part of large corporations, whose main task is to determine the corporate management rating [2].

At the moment certain methodological principles are being formed and rating management practices are being implemented. The difficulty in solving the abovementioned problems, as well as the increasing role of information technology in the adoption and implementation of managerial decisions have determined the urgency of a problem of developing a certain classification of methods for the formation of rating assessment, which follows from the theory of rating management and scientifically based techniques.

It can be noted that when determining the purpose of the rating management, it is necessary to take into account certain dependencies:

- subject of rating management, which determines a certain class;

- type of rating;

- a way to obtain a rating [3].

To solve the tasks, it is necessary to choose a method for determining the ranking. This direction depends on the qualitative characteristics of the initial information. For this purpose, the classification of methods that form rating score and methods for constructing ratings is proposed in Fig. 1.
One of the main conditions for effective rating management is to justify and choose the methodology for a rating building. In this case, the following tasks need to be solved:

- definition of the initial data used for the selected calculations and sources of their obtaining;

- selection and construction of indicators that evaluate and compare alternatives;

- selection of methods for calculating the values of rating indicators;

- definition or development of calculation scales for comparison techniques;

- evaluation of the costs for conducting these works.

The purpose of the rating management depends on the rating information, that is, the information space where rating is carried out and the method for obtaining a rating.

So, with the solution of these tasks, it can be noted that rating management can act as a determinant of the state of economic systems and processes, where the rating is used for the processing, planning and regulation of the system.

From the appropriate features of the rating methods, the following rating definitions are used for rating management:

- for analysis, the rating is used as a management function;

- rating is the result of a comprehensive analysis of certain systems of economic management, where the calculation of the rating assessment uses the principle of

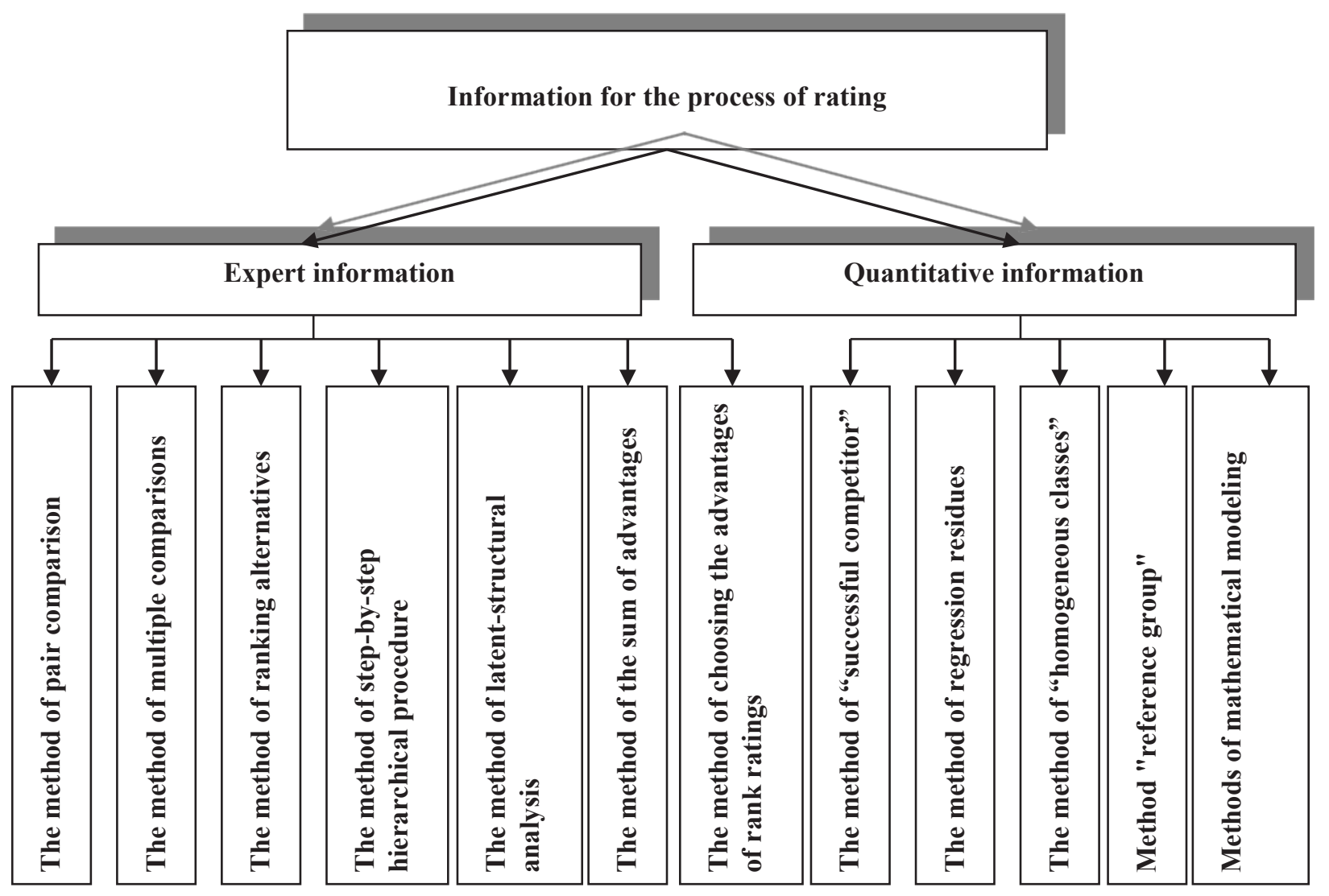

Fig. 1. Classification of methods that form a rating estimation 
compliance with the functioning of this or that economic system of the list of certain criteria.

Rating evaluation is based on the interaction of such groups of elements: objects, subjects of evaluation and consumers of the rating. A determination and selection of a rating model depends on certain management conditions that the consumer uses in the rating [4].

So, we can define certain tasks of the customer:

1) the need to determine the interaction of objects of evaluation;

2) to select one or several objects of interaction among the numerous selected objects;

3 ) to determine the interaction with another class of objects that have already been worked out, with the subsequent need to increase their effectiveness.

As for the first two tasks, they have been used in the rating management for a long time, because for the first task, the rating is based on the rating scale, and for the second one - ranking rating models.

But the third task evaluates a plurality of objects, both in the external and internal environment of the rating customer.

In order to select the most rational rating models, it is necessary to carry out the merger according to a gen- eralized classification, which combines the evaluation procedure, the task of management, the consideration of cyclicality and dynamism.

Therefore, the scheme of the relationship between the stages of the methodology of rating construction is suggested, which takes into account the peculiarity of the evaluation process and the result that we receive, and also takes into account those differences between the management tasks and the terms of the rating, considering those properties of the objects, for solving of which rating assessment is used.

To solve the proposed conditions, a methodology for rating construction was created, whose main stages are displayed in Fig. 2.

First of all, homogeneous groups of rating entities are selected. This stage is due to the fact that at the stage of rating assessment for a sample of objects, it is necessary to use the assessment not only of quantitative indicators, but also to take into account qualitative information of the obtained ratings.

The application of this stage allows excluding from the following review rating objects that are not sufficiently necessary or those with an indefinite economic status. With the help of a group of cluster analysis meth-

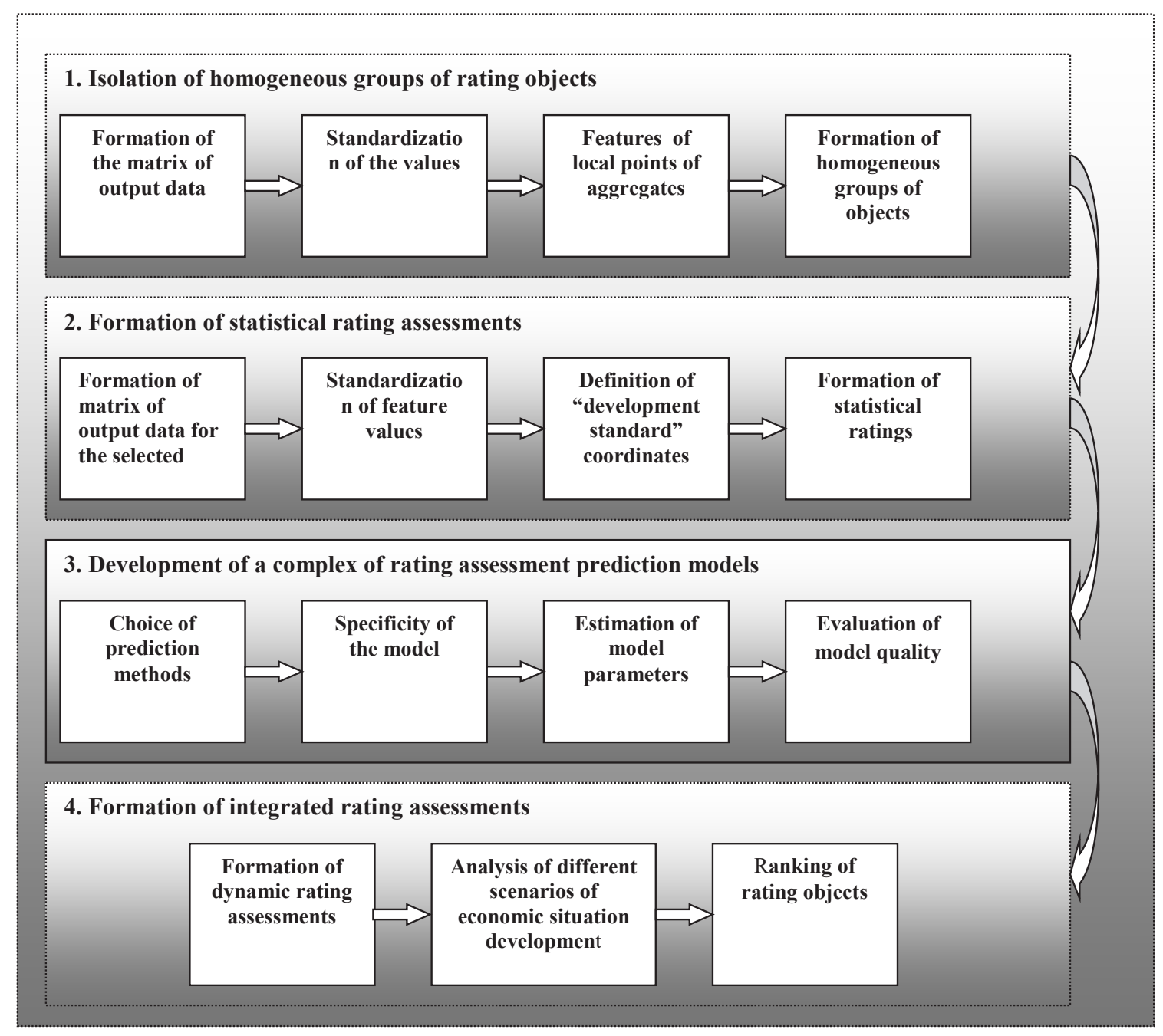

Fig. 2. The diagram of the relationship between the stages of the methodology of ratings formation 
ods: hierarchical, iterative, and agglomerate ones, it is possible to group homogeneous objects into clusters that allow problem solving at this stage [5].

To combine the ranking objects into clusters, the cluster search method is used, which has the following advantages: there are no restrictions on the characteristics of the objects and their number, and it allows grouping non-intersecting clusters. The essence of the algorithm of the iterative method is to use specific given study space, where the movement is carried out in order to find such clusters that correspond to certain classification features.

At the next stage of the methodology, a rating is calculated, on the basis of which a comprehensive assessment of rating objects can be made and an analysis of their status can be carried out. In order to obtain such an estimate, one method of taxonomy, the development level method, is suggested. An important advantage of the method is that it is possible to obtain, in a quantitative interpretation, an assessment of the status of a rating object that will act as a definite integral indicator, calculated in the range from 0 to 1 , which takes into account the influence of related indicators.

Rating assessments can be used for the calculation of not only the whole set of indicators, but also of its individual components. Depending on the calculated local ratings, a thorough diagnosis of the state of the object can be carried out, an analysis of all factors that have a significant impact on ratings and determine the dominant areas of management for the object for which rating assessment has been carried out.

Trend models allow selecting the dependence of the analyzed index $(y)$ on time $(t)$, that is, $y=f(t)$. The "time" variable stands in this case for some generalized development factor, which accumulates the influence of a number of factors operating in the given time period and those which, as a rule, are multi-vectored. The combined effect of these factors reflects a certain tendency to change the time dependence of the corresponding indicator. This dependence is described by this trend, in the form of a trend model, which is written by the function $f(t)$, which expresses the general influence of all factors operating at this time on the investigated index [6].

Therefore, in this case, the equation of the trend model will be based on the smoothed data, which, as a rule, greatly improves the efficiency of this model.

A linear or nonlinear functional dependence, whose parameters need to be evaluated, can serve as a trend model equation. Determining the appearance of a function is carried out empirically in most cases. Thus, the formatting of the system of static rating assessments is carried out, as in the whole set of indicators, and by the selected groups, which allows carrying out a rating assessment of this object and conduct diagnostics of their condition.

So, the construction of a trend model can be done directly from empirical data on the dynamics of the indicator, using the methods of correlation-regression analysis, as well as with the use of the previous smoothing of these data. The smoothing procedure is used to reject the effects of individual inequalities of real data that may have predictable character and may give a distorted general tendency. Therefore, in this case, the equation of the trend model will be based on the smoothed data, which, as a rule, greatly improves the efficiency of this model.

Analysis of the variation of the above characteristics gives the opportunity to choose the form of dependence, which best of all describes the evolutionary component of the investigated process. After choosing a dependency, you need to evaluate its parameters. The most common method for evaluating the parameters of a linear model is usually the least square method. To evaluate the parameters of nonlinear models, nonlinear functions are used which are written in the form of linear models, iterative methods, and Tayle's method using logarithmic transformations.

It should also be noted that the parameters of the equation of the trend depend on the errors and can change their values when removed from the row of a certain part of the indicators. This affects the accuracy of the estimates of certain levels of time series. In addition, the parameters of the trend equation that can be obtained by the least square method remain unchanged throughout the given period, so adaptive methods are more effective in solving the task of constructing a flexible rating system for rating entities.

The latter ones, on the basis of structural and parametric adaptation, allow constructing models that can be adjusted taking into account the results of the forecast in the previous step, and differentiating the informational value of the series, able to respond promptly to changing conditions, and on this basis give more accurate forecasts. The method of exponential smoothing is one of such methods.

Sometimes adaptive models of forecasting use models built on autoregression. Autoregressive models are rather good to describe fluctuations of the indexes of a series and can be used for unstable tendencies. The general construction of the forecasting problem with the help of autoregression models is as follows: to find the value of integral indicators of the state of rating objects for the future period on a number of previous values with the help of some regression equation.

Therefore, for the implementation of the next stage of the proposed scheme of the relationship between the stages of the methodology of rating assessment, an integrated approach to rating assessments forecasting based on integral indicators of object state determining is used.

At the stage where the predictive value of rating assessments is calculated, it is necessary to apply not only the point but also the interval forecast, which allows selecting such scenarios for the development of a particular economic situation that takes into account the negative and positive factors.

An important stage after using the scheme of the relationship between the stages of the rating methodology in the rating management is the process of making managerial decisions. It is important to consider this process on the basis of reliable gathered information, its processing and analysis, which allows identifying not only the 
current situation, but also an alternative to development. So, the final choice of alternatives for the formation of managerial decisions is made on the basis of changes in the status of objects. Implementation of selected managerial decisions should include the development of a stage plan for their implementation, a comprehensive analysis, as well as bringing the plan of decisions to the executives and monitoring their implementation.

In conditions of non-stable economic environment, the process of developing and adopting effective decisions based on the rating for each economic entity has its own characteristics, which are determined by the nature and inherent features of its activities, the organizational structure and the external and internal management system.

The necessary stage of implementation of management decisions involves defining the criteria for the effectiveness of the developed decision lists and their evaluation, for which qualitative and quantitative indicators are used. These criteria take into account the efficiency of resource turnover, their competitiveness, improvement of the investment climate, and others.

Thus, the definition of criteria for the effectiveness of management decisions implies a comprehensive development that allows you to explore alternative rating management. At this stage it is important to use the hierarchy analysis method, which calculates the efficiency of the rating management of the selected strategy on the basis of computing the integral priority vector, where the components of the vector are compared with the smallest value of the alternatives to the solutions.

The most important stage of the developed scheme of interconnections is the analysis of various scenarios of economic situation development in the process of managerial decision making, where it is important to deduct costs. On the basis of economic modeling methods, estimation of expenses, necessary for realization of these alternative management decisions is carried out [7]. The formulation of a particular economic model should include: specification of the model, formation of the corresponding information base, evaluation of model parameters and analysis of the effectiveness of its application.

The specification of this model allows us to define a structure that describes certain parameters and functional dependencies. Parameters of this model should be independent of each other, since a strong connection between them can lead to the effect of multicollinearity, which causes instability and insecurity of the values of model parameter estimates.

Information data of the model should be sufficiently disclosed in terms of volume and homogeneous in their composition. In this case, the statistical values of the estimates of the parameters of this model should reflect the reliability of the amount of data. But the application in the calculation of a large amount of data may cause changes in the homogeneity of the aggregate of indicators.

The obtained rating values can be used to calculate the vector for certain costs, where the corresponding element of the given stage may reflect the specific weight of expenses that is necessary for implementation of alternatives of rating management in the total amount of expenses. This gives grounds for obtaining a scheme of interconnected stages of the methodology for the formation of such rating assessments, which allows rejecting certain indicators of objects in the rating process that will lead to excessive costs when making effective managerial decisions.

Therefore, the choice of the resulting management decision is made depending on the resulting vector, where all the elements are calculated by comparing the effect of their application and the costs reflecting the implementation of these alternative management decisions.

Conclusions. Thus, it has been determined that the rating in the rating management of regional economic systems is a necessary element of the implementation of all functions, since it can be applied at all stages of the management cycle for the realization of their various steps, as it is both a tool and a management objective. Therefore, on the basis of conducted research and analysis of the content characteristics that are inherent in the rating process, a general classification of the rating methods has been built and the scheme of the relationship between the stages of the methodology of the formation of rating assessments in the system of the adoption of effective management decisions has been suggested.

\section{References.}

1. Blahun, I. S., Dmytryshyn, L. I. and Romankiv, I. M., 2012. Approaches to the formation of regional development concepts. Bulletin Prikarpatsksy University. Series “Economy”, 9, pp. 130-134.

2. Mironov, Y. B., 2014. Strengths and weaknesses of various indicators of bank ratings. Scientific Bulletin of Kherson State University. Series of "Economics", 6(5), pp. 26-30.

3. Myronova, L. H., 2011. Classification of rating models and decision-making. Efektyvna ekonomika [online]. Available at: <http://www.economy. nayka.com.ua/> [Accessed 10 March 2017].

4. Alymov, O. M., Mikitenko, V. V. and Lytsur, I. M., 2013. Systems of comprehensive evaluation of sustainable development potential of Ukraine. Kyiv: State Institution "Institute of Environmental Economics and Sustainable Development of NAS of Ukraine".

5. Melnyk, O. H., 2012. Methods of rating companies. $A k$ tualni problemy ekonomiky [online], 12, pp. 84-94. Available at: <http://nbuv.gov.ua/UJRN/ape_2012_12_12> [Accessed 12 May 2017].

6. Novikova, A. F., Amosha, A. I. and Antoniuk, V. P., 2012. Sustainable development of industrial region: social aspects. Donetsk: NAS of Ukraine, Institute of Economics industry.

7. Prykhodko, M. M., 2017. Floods and their management in the Carpathian region of Ukraine. Naukovyi Visnyk Natsionalnoho Hirnychoho Universytetu, 2, pp. 112-117.

\section{Особливості етапів формування рейтингових оцінок у системі рейтингового управління}

\section{І. Л. Боднарук, Л. С. Шлапак}

Івано-Франківський національний технічний університет нафти і газу, м. Івано-Франківськ, Україна, е-таil: irynabodnaruk17@gmail.com; tzn@nung.edu.ua 
Мета. Дослідження змістовних ознак, які властиві процесу рейтингування та методам формування рейтингової оцінки, що дають змогу забезпечити процедуру ефективності прийняття управлінських рішень.

Методика. Теоретичні та практичні результати дослідження отримані за допомогою таких методів: синтезу, аналізу - для виявлення особливостей формування рейтингу та аналізу методів оцінювання; конструктивно-логічний метод - для побудови моделі прийняття рішень у системі рейтингового управління; логічного узагальнення, економікоматематичного моделювання - для впровадження науково-методичного підходу щодо рейтингового оцінювання.

Результати. Визначено, концепція ухвалення рішень замовником на основі розрахованих рейтингів при реалізації певних функцій управління була покладена в основу рейтингування та рейтингового управління. На основі здійсненого аналізу було запропоновано загальну класифікацію методів формування рейтингової оцінки, що дало змогу забезпечити процедуру оцінювання та ефективність прийняття управлінських рішень, а також побудувати схему взаємозв'язку етапів методики формування рейтингових оцінок.

Наукова новизна. Побудована класифікація методів та етапів формування рейтингових оцінок дає можливість ураховувати особливості процесу обчислення рейтингу у прийнятті певних завдань управлінських рішень, і $є$ визначальною як проблема поглибленого вивчення теорії рейтингового управління, так і розроблення й використання науково обгрунтованих моделей рейтингового оцінювання.

Практична значимість. Розроблена схема взаємозв'язку етапів методики формування рейтингових оцінок, що представлена як гнучка, інтегрована система, яка охоплює способи, методи й моделі в системі управління на основі рейтингу, що дозволить ухвалити й прийняти ефективні управлінські рішення.

Ключові слова: рейтингова оцінка, рейтингове управління, рейтингування, класифікація, оцінювання

\section{Особенности этапов формирования рейтинговых оценок в системе рейтингового управления}

\section{И. Л. Боднарук, Л. С. Шлапак}

Ивано-Франковский национальный технический университет нефти и газа, г. Ивано-Франковск, Украина, e-mail: irynabodnaruk17@gmail.com; tzn@nung.edu.
Цель. Исследование содержательных признаков, присущих процессу рейтингования и методам формирования рейтинговой оценки, позволяющих обеспечить процедуру эффективности принятия управленческих решений.

Методика. Теоретические и практические результаты исследования получены с помощью следующих методов: синтеза, анализа - для выявления особенностей формирования рейтинга и анализа методов оценки; конструктивно-логический метод - для построения модели принятия решений в системе рейтингового управления; логического обобщения, экономико-математического моделирования - для внедрения научно-методического подхода к рейтинговой оценке.

Результаты. Определено, концепция принятия решений заказчиком на основе рассчитанных рейтингов при реализации определенных функций управления была положена в основу рейтингования и рейтингового управления. На основе проведенного анализа была предложена общая классификация методов формирования рейтинговой оценки, что позволило обеспечить процедуру оценки и эффективность принятия управленческих решений, а также построить схему взаимосвязи этапов методики формирования рейтинговых оценок.

Научная новизна. Построенная классификация методов и этапов формирования рейтинговых оценок дает возможность учитывать особенности процесса вычисления рейтинга в принятии определенных задач управленческих решений, и является определяющей как проблема углубленного изучения теории рейтингового управления, так и разработки и использования научно обоснованных моделей рейтинговой оценки.

Практическая значимость. Разработана схема взаимосвязи этапов методики формирования рейтинговых оценок, которая представлена как гибкая, интегрированная система, которая охватывает способы, методы и модели в системе управления на основе рейтинга, что позволит утвердить и принять эффективные управленческие решения.

Ключевые слова: рейтинговая оценка, рейтинговое управления, рейтингование, классификация, оценка

Рекомендовано до публікації докт. екон. наук М.О.Данилюком. Дата надходження рукопису 14.02.17. 